\title{
The Meaning of Quality in
}

\section{Kinship Foster Care: Caregiver, Child, and Worker Perspectives}

\author{
Robert Chipman, Susan J. Wells, \& Michelle A. Johnson
}

\begin{abstract}
Though principles, guidelines, and procedures for assessing the quality of foster care in kinship settings have been introduced, research on the factors that mediate the quality and outcome of kinship care has been minimal. To provide insight into these factors from the perspectives of kinship stakeholders, this article presents findings from a qualitative study conducted with kinship caregivers, children living with relatives, and caseworkers of children in kinship placements. Their views on quality care in kinship homes, including factors to consider in the selection and evaluation of kinship placements and opinions of how kinship and nonkinship foster care differ, make unique contributions to the development of standards and measures for kinship foster care assessment. Findings confirm the salience of specific factors present in existing guidelines, build on existing recommendations for the selection and evaluation of kinship homes, and highlight important policy and practice issues for consideration with kinship families.
\end{abstract}

THE DEVELOPMENT OF STANDARDS for kinship foster care requires states and agencies to comply with federal mandates and funding requirements while remaining sensitive to the differences between nonkinship and kin arrangements. Many states have responded by applying the same regulations and policies to both types of placements (Everett, 1995; Gleeson \& Craig, 1994). Others have developed separate licensing and approval standards for relative homes that employ less rigorous screening, monitoring, and evaluation procedures. Though the former approach may seek to provide uniform protection of children and treatment of caregivers, standards for nonkinship care may be intrusive or unsuitable for kinship homes. For example, foster boarding requirements may exclude appropriate but economically disadvantaged relatives from assuming care (Takas, 1992, 1994). At the same time, relaxing standards for kinship placements may leave children at risk of subsequent maltreatment and without the assistance made available to children in nonkinship placements (Berrick,
Barth, \& Needell, 1994; Iglehart, 1994), thereby sanctioning a level of care that is not only substandard but potentially in violation of federal regulations.

To partly address these issues, some states (e.g., Illinois, New York) have developed specific approval and reimbursement procedures for kinship caregivers, such as applying safety standards (e.g., criminal history checks) while waiving requirements unrelated to safety (e.g., bedroom square footage, foster parent training). The approach in part reflects standards developed by the Child Welfare League of America (CWLA) that essentially mirror requirements for nonkinship foster care while highlighting important safety considerations in evaluating kinship families, such as the ability of the relative to protect the child from the parent (see Table 1). The CWLA standards also provide flexibility in areas unrelated to child protection, such as the number of bedrooms in the home (CWLA, 1994, 1999). The policymaking body of the American Bar Association ( $\mathrm{ABA}$ ) has 
Table 1. Child Welfare League of America's Standards for Kinship Foster Family Assessment (CWLA, 1994, 1999)

1. Relationship between child and relative

2. Ability and desire of relative to protect the child from the parent

3. Safety and nurturing environment of home

4. Willingness of family to accept child

5. Ability of parent to meet child's developmental needs

6. Relationship between birth parent and relative

7. Family dynamics in kinship home related to abuse or neglect of the child

8. Presence of substance abuse

9. Willingness to cooperate with the agency

10. Existing support systems

11. Number of children in the home and their status (e.g., HIV status, other medical conditions, drug use)

12. Health status of kinship caretakers

13. Age of kinship caretakers in light of child's long-term needs

14. The possibility that family members will pressure the child to recant any allegations of abuse

also approved guidelines for state courts, child welfare agencies, and attorneys to follow when children are placed in kinship homes. The ABA guidelines include recommendations for aggressive searches for kin, background screening of kinship caregivers, education on legal permanency for children, notice to providers so that they can be heard in the judicial process, support for medical consent, and resources for short-term and permanent kinship arrangements $(A B A$, 1999). Though much of the empirical work on kinship care is descriptive, such as the documentation of the rise in numbers of children in kinship foster care and the policy climate in which this has occurred, the literature provides some empirical support for items in existing standards. Findings from studies that have compared both child and caregiver characteristics, kinship care outcomes, and the provision of agency services in kin versus nonkinship foster care settings highlight important considerations in the assessment and evaluation of quality in kinship care.

\section{Characteristics of Kinship Caregivers}

When compared to nonkinship foster parents, kin caregivers are more likely to be older, African American women (Berrick et al., 1994; Gebel, 1996; LeProhn, 1994; Thornton, 1991), single, and head of household (Berrick et al., 1994; LeProhn, 1994), with less education and lower incomes (Berrick et al., 1994; Gebel, 1996; LeProhn, 1994). Gebel (1996) reported that relative caregivers were less likely to be employed outside of the home while Berrick et al., (1994) found the opposite to be true, though both found relatives more likely to report that they were not in good health.
Kinship caregivers also have different attitudes about child rearing, the children in their care, and their role as caregivers. LeProhn (1994) found that kinship caregivers placed more emphasis on maintaining contact with biological families, felt more responsible for helping with the child's emotional problems, and felt more accountable for tasks related to basic parenting. Berrick and others (1994) found they were also more likely to think that the child had been in no danger prior to placement. Gebel reported that relative caregivers had more favorable attitudes toward physical punishment and higher expectations for the child than nonrelative foster parents, but were less likely to describe the child as "difficult to handle." Thornton (1991) found relative caregivers more hesitant to adopt children in their care, though other investigators found no differences in kinship caregivers' willingness to adopt (Gebel, 1996; Testa, 1993; Testa, Shook, \& Cohen, 1996).

\section{Children in Kinship Care}

The available research, while limited, suggests important differences between children living in kin and nonkinship settings. Children in kinship foster care tend to be younger (Iglehart, 1994) and African American (Fox, Frasch, \& Berrick, 2000 ) with slightly fewer behavioral and educational problems (Benedict, Zuravin, \& Stallings, 1996; Berrick et al., 1994), somewhat better mental health outcomes (Benedict et al., 1996; Iglehart, 1994), and fewer developmental issues (Benedict et al., 1996) when compared with children in nonkinship settings. Yet when compared to normative samples, children in kinship care still have significantly more problems than children in the general population (Berrick et al., 1994), including greater health care needs and more behavioral problems (Dubowitz, Feigelman, Harrington, Starr, Zuravin, \& Sawyer, 1994).

Children in kin and nonkinship care also tend to differ in terms of the safety of the neighborhoods within which they reside. In their study of 100 children in kinship and nonkinship care, Fox and others (2000) found that kinship homes were more likely to be located in a "generally dangerous appearing area" with more poorly kept homes, more garbage, more loitering, and more outside hazards than nonkinship homes. Further, children in kinship care were more likely to live in public housing and less likely to live in single-dwelling homes. This is notable in that the children in the study who lived in public housing reported significantly higher levels of exposure to violence when compared to other children. Along these lines, children in kinship placements were more likely than children in nonkinship placements to report having witnessed a stabbing and/or shooting at least once "in or near [their] home" (Fox et al., 2000, p. 127).

Despite neighborhood perils, children in both kin and nonkinship settings in the Fox and others study (2000) experienced similarly high levels of caregiver support for overall physical well-being, future expectations, and school-related well-being. In fact, children in kinship placements were more likely than children in nonkinship placements to receive help 
with homework and less likely to report that the "people in [their] home say mean things to [them]" (Fox et al., 2000, p. 127). Research also suggests that children in kin placements tend to both live with and have regular contact with biological siblings not living in the same home (Fox et al., 2000), and are more likely than children in nonkin placements to have more contact with their biological parents (Berrick et al., 1994; Fox et al., 2000).

\section{Kinship Care Outcomes}

In terms of service outcomes, studies suggest that kinship placements tend to be more stable than other types of placements (Benedict et al., 1996; Fox et al., 2000; Iglehart, 1994), though reunification and adoption rates have been found to be slower for children in kinship care (Barth, Courtney, Berrick, \& Albert, 1994; Courtney, 1994; Dubowitz et al., 1994; Goerge, 1990; Iglehart, 1994; Testa, 1993; Wulczyn \& Goerge, 1992). Some research has indicated that children living with relatives tend to remain in care longer than children in other forms of out-of-home care (Benedict \& White, 1991; Fox et al., 2000; Wulczyn \& Goerge, 1992), though Benedict and others (1996) and Iglehart (1994) found no difference between the overall length of stay for children in kin and nonkinship placements.

\section{Agency Services Provided}

Agency support represents a potential mediating factor that may affect both the quality and outcome of kinship care. When compared to nonkinship placements, at least four groups of researchers have found that social service agencies provide less funding and fewer services to kinship placements, such as agency supervision, respite care, day care, support groups, and training (Berrick et al.,1994; Chipman, Shepherd, \& Wells, 2000; Gebel, 1996; Iglehart, 1994). Further, Berrick and others (1994) found that more children in nonkinship placements received mental health services when compared to children in kinship care. Iglehart (1994) found that caseworkers do not know adolescents in kinship homes as well as those in nonkinship care, suggesting that agencies may have less contact with these youth.

While standards exist for selecting and evaluating foster homes, these findings indicate the need for standards that take into account the distinct characteristics and needs of kin caregivers and the children in their care. This study builds on the existing literature by examining kinship stakeholders' perspectives on criteria of importance in the selection and evaluation of kinship homes, factors that mediate the quality and outcome of kinship care, and perceived differences between kinship and nonkinship placements. A secondary goal of the study was to determine whether stakeholder perceptions differed by region or racial/ethnic group. Guidelines for the licensing and approval of kinship caregivers, such as those developed by CWLA and ABA, and those set forth by the fed- eral government for purposes of Title IV-E foster care payment reimbursement, provide important recommendations for the assessment of quality in kinship foster care. Though kinship care policies have been formalized in many states, empirical research on the quality of care in kinship arrangements and the meaning of quality to kinship caregivers, children in relative care, and caseworkers of children in kinship placements has been has been minimal. Recommendations follow for the development of standards and measurement of quality in kinship placements and considerations for policy, practice, and future research.

\section{Methodology}

Twenty-four focus group interviews were planned with samples of kinship caregivers, children in kinship care, and caseworkers of children placed in kinship settings. ${ }^{1}$ As a data collection technique, the focus group is inexpensive, flexible, and useful when gaps exist between groups due to factors such as language, culture, region, or differences in perceived or actual power (Morgan \& Krueger, 1993). Limitations of focus groups are also linked to the group process: The group setting may interfere with individual expression, risk domination by loquacious individuals, or make the discussion of sensitive topics difficult, thereby increasing requirements for skilled facilitation (Fontana \& Frey, 1994). Despite limitations, the focus group technique was selected to capture first-person experiences and the richness of data resulting from the dynamics of group interaction.

To capture a broad range of experiences and account for differences in perspectives due to policy variations, samples were stratified by state, region, and race/ethnicity. Stakeholders were selected from locations in two states: Illinois, which has a state-administered child welfare system with kinship care policies and procedures, and North Carolina, which has a state-regulated and county-administered system without statewide kinship care policies at the time of the study. Prospective sites were selected in coordination with the Illinois Department of Children and Family Services (IDCFS), the North Carolina Department of Social Services (NCDSS), and the North Carolina Commission on Indian Affairs (NCCIA). Eligible participants included relative caregivers of the targeted race/ethnicity who had cared for a child in custody within the previous 2 years. Children older than 10 years of age who were living with a relative at the time of recruitment were eligible for the study and considered to have the cognitive and communicative skills to reflect upon and describe their experiences. Sites self-selected caseworkers with kinship placement experience for study involvement. The primary selection criteria for all groups included the participant's willingness to participate. Financial incentives were provided to participating caregivers $(\$ 20)$ and children $(\$ 10)$.

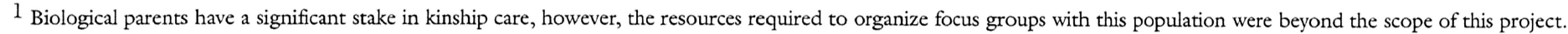


With the exception of one racially mixed caregiver group, trained moderators were matched to caregivers and children of the same racial or ethnic background to enhance understanding between moderators and participants (Fontana \& Frey, 1994; Jarrett, 1993; Padgett, 1998). All proceedings were recorded and transcribed, with the exception of one session that was not taped and one tape that was found to be incomprehensible upon transcription. The topic guides, which had been developed and piloted with caregivers, children, and caseworkers, did not require significant revision following the pilots. Therefore, the pilot data are included in the presented results.

\section{Sample Characteristics}

Twelve focus groups were conducted in five North Carolina counties and one urban site in Illinois (see Table 2). Participants included 33 caregivers (representing 25 households), 7 children (representing 3 households), and 30 caseworkers.

For the caregivers for which demographic information was available (North Carolina only), the 19 female and six male caregivers ranged in age from 25 to 65 years. These participants included 12 grandmothers, six aunts, five grandfathers, one great-grandmother, and one uncle. Fifty-two percent of the sample was African American. Four caregivers from three households were licensed foster parents receiving foster care payments. Unlicensed relatives were receiving AFDC funding for the children in their care. The number of relative children in the households ranged from one to six and caregivers reported having the children in their care between 2 months and 8 years. Most children had entered care as a result of parental maltreatment involving substance abuse problems. Child participants ranged in age from 11 to 18 years and had been living with grandparents or an uncle and/or aunt from 1 to 4 years. The children in one group consisted of a single sibling group.

The number of caseworkers participating in each focus group ranged from two in rural North Carolina to 12 in urban Illinois. In the latter case, all caseworkers serving kinship placements in the county participated in the study. The groups included both African American and Caucasian participants. The majority were female with the exception of the urban Illinois group which was mostly male and included Latino/a participants. The ages of caseworkers ranged from 21 to 60 years. All caseworkers had a minimum of a college degree at the time of the study and reported 0 to 26 years of experience with kinship placements. Reported caseload sizes ranged from 0 to 37 cases. In at least one group, a worker with 0 cases was later found to be a supervisor after the interview was well under way. Though not part of the study design, the supervisor's responses did not radically vary from the worker discussions, and are, therefore, included in the findings.

\section{Study Limitations}

The successful organization of each focus group required significant assistance from local agency personnel, including identifying eligible participants, obtaining client consents to be contacted for the study, provision of contact information, and in some cases, following up with clients to encourage participation. Unfortunately, some agencies lacked the resources to provide the support necessary to conduct all of the planned focus groups within the study time frame. The cancellation of these sessions resulted in the underrepresentation of certain groups, including Native American and rural Illinois participants. Limited pools of potential participants were another major obstacle in many sites, especially for the children's groups. Sites were selected based, in part, on the number of children in kinship care. Yet kinship caseloads in some sites were not large enough to successfully recruit targeted group sizes of six to 12 participants of children over 10 years of age. The reduced number of groups somewhat limited the intergroup comparisons (e.g., urban/rural comparisons) across and within states.

Table 2. Focus Group Characteristics

\begin{tabular}{llcc}
\hline $\begin{array}{l}\text { NORTH CAROLINA } \\
\text { Participants }\end{array}$ & \multicolumn{1}{c}{$\begin{array}{c}\text { Race/ } \\
\text { ethnicity }\end{array}$} & $\begin{array}{c}\text { Urban } \\
\text { sites }\end{array}$ & $\begin{array}{c}\text { Rural } \\
\text { sites }\end{array}$ \\
\hline Caregivers & African American & A & B \\
& Caucasian & C & - \\
Children & African American, Caucasian & E & - \\
Caseworkers & Caucasian & C & D \\
& African American and Caucasian & E & - \\
\hline ILLINOIS & & E & Urban \\
Participants & Race/ & sites & Rural \\
& ethnicity & F & - \\
\hline Caregivers & African American & F & - \\
Children & Caucasian & F & - \\
Caseworkers & African American, Caucasian, Latino/a & & \\
\hline
\end{tabular}

Note. The North Carolina counties are labeled A, B, C, D, and E.

The Illinois site is labeled $\mathrm{F}$. 


\section{Findings}

The findings represent the results of 12 focus groups conducted using topic guides designed to elicit the values, perspectives, and experiences of kinship caregivers, children in relative care, and caseworkers with respect to selecting and evaluating kinship caregivers; important outcomes and intervening factors in the quality of kinship care; services needed by kinship families; and how kinship care differs from traditional foster care and the care of biological children.

\section{Selection and Evaluation Criteria}

The process of assessing a caregiver's capacity to provide adequate care before a child enters placement (i.e. selection) and the process of assessing the care provided after a child is placed (i.e. evaluation) are conceptually distinct activities. Participants, however, did not make distinctions between the factors important in selecting and evaluating kinship homes. To tap the first, participants were asked what they would look for if they had to select a relative to care for their child. For the second, they were asked, "if the next-door neighbors were providing care for their own grandchild, how would the informants be able to tell whether that child was well cared for?" Participants often cited the same characteristics or behaviors in response to each question. Responses are presented in Tables 3 and 4.

The selection and evaluation criteria identified by participants focused largely on the provision of basic care, including the overlapping dimensions of child safety, physical care, emotional care, and support for the child's normal growth and development. While caseworkers focused on issues of child safety and permanency, such as background safety checks, the caregiver's child-rearing history, and the caregiver's commitment to care for children as long as necessary, caregivers focused on the caregiver's emotional capacities and characteristics. A desirable caregiver was described as a person who can provide children with love and moral and spiritual guidance. Participants in several groups expressed concern for protecting the child from the consequences of negative behaviors by members of the caregiver's household, such as criminal activity, child maltreatment, domestic violence, and substance abuse. Though not a major topic of discussion, several caseworkers believed that kinship homes should protect children from hazards in the physical environment in and around the home. Some caregivers, children, and caseworkers focused on the caregiver's capacity to provide stable, physical care by expressing preferences for employed and financially stable caregivers. Participants agreed widely about the importance of the caregiver's interactions with the child, and expressed particular concern about the caregiver's representation of the biological parent to the child. Caseworkers and caregivers agreed that the caregiver should refrain from disparaging the child's parent $(s)$ in order to protect the child's emotional health.

Most of the screening and evaluation criteria discussed do not apply uniquely to kinship care; every substitute care placement should provide all aspects of basic care. The issues raised that pertain more specifically to kinship care included the placement process itself, screening and licensing standards, protection of the child from continued maltreatment by the biological parent, discipline, and the caregiver's age and health. These issues are elaborated upon below.

Placement in Kinship Care. Unlike nonkinship foster parents, most kinship caregivers from the participating states were not licensed before the child was placed in their care. As a result, caseworkers may have had little information about the caregiver at the time of placement, particularly in emergency situations. Many caregivers reported having children placed in their homes without an assessment; others reported not having a choice about accepting the child for placement.

\section{All of a sudden this DCFS worker calls me and tells me I've got to take these four kids. This lady is just like, "I've got to go to a meeting and you've got to take these chil- dren home with you." I'm sitting there in shock... She kept typing this paper up. She ushered me out of her office and put these kids in my car. I'm sitting there, like Lord, what happened? What am I going to do? - Caregiver}

Workers participating in the focus groups generally reported that some screening occurs prior to placement, though subsequent assessments sometimes reveal significant issues that if known in advance, would have otherwise precluded the placement decision.

In addition to raising child safety issues, participants reported that the unplanned placements created problems for members of the caregiver's household and the child being placed. To minimize strain on all parties, some participants suggested that placing agencies prepare families by conducting pre-placement meetings involving the children, kinship families, and biological parents to discuss the child's needs and each party's expectations of the placement.

The people should have a meeting with the entire family which the child is going to.... It'd be like prenatal care I guess, but for the family... You know to bave them understand how the children and parents feel. -Child

Screening and Licensing Standards. Caseworkers generally believed that the agency should not hold kin to the same standards as nonkinship homes (e.g., square footage requirements, training requirements, number of children per room) but recognized a need to apply minimum standards. They were at the same time unsure about how to weigh the relative importance of kinship versus other factors when screening homes.

If it's a difference between being able to place a child with relatives and not being able to ... then it's impor- 
Table 3. Selection Criteria

\begin{tabular}{|c|c|c|c|c|c|c|c|c|c|c|c|}
\hline \multirow{4}{*}{$\frac{\text { Criterion }}{\text { Willingness to work towards reunification }}$} & \multicolumn{4}{|c|}{ Caseworkers } & \multicolumn{5}{|c|}{ Caregivers } & \multicolumn{2}{|c|}{ Children } \\
\hline & \multicolumn{3}{|c|}{ NC } & \multirow{2}{*}{ IL } & \multicolumn{4}{|c|}{ NC } & \multirow{2}{*}{$\mathrm{IL}$} & \multirow{2}{*}{$\frac{\mathrm{NC}}{\mathrm{C}}$} & \multirow{2}{*}{$\begin{array}{ll}\mathrm{IL} \\
\mathrm{F}\end{array}$} \\
\hline & $\mathrm{D}$ & $\mathrm{E}$ & $\mathrm{C}$ & & $\mathrm{B}$ & $\mathrm{D}$ & $\mathrm{A}$ & $\mathrm{C}$ & & & \\
\hline & ! & घ & & घ & & & & & & & \\
\hline Caregiver's motivation & - & & & " & & & & - & & & \\
\hline $\begin{array}{l}\text { Commitment to care for the child } \\
\text { as long as necessary }\end{array}$ & a & - & घ & - & & & & & & & \\
\hline $\begin{array}{l}\text { Caregiver's capacity to protect the child } \\
\text { from the biological parent }\end{array}$ & - & घ & & & & & & & & & घ \\
\hline $\begin{array}{l}\text { Caregiver believes maltreatment } \\
\text { allegations against parent }\end{array}$ & & घ & - & - & & & & & & & \\
\hline Caregiver's family history & & & 口 & 口 & & & & & & & \\
\hline Protective services checks & a & $\square$ & - & 口 & & - & & & & & \\
\hline Criminal records and police checks & 口 & - & - & 口 & & & & & & & \\
\hline $\begin{array}{l}\text { Child knows and has an existing } \\
\text { relationship with caregiver }\end{array}$ & घ & घ & घ & घ & & & & & & - & \\
\hline $\begin{array}{l}\text { Child knows and has an existing } \\
\text { relationship with the caregiver's children }\end{array}$ & & & - & & & & & & & & a \\
\hline Caregiver's age relative to the child's needs & " & & & & & & - & - & - & & a \\
\hline Caregiver's health relative to the child's needs & " & 口 & घ & a & m & & a & a & " & a & \\
\hline Caregiver capacity to provide love & & & & & - & (1 & & a & a & - & \\
\hline Caregiver has patience & & & & & & - & & $\square$ & - & & \\
\hline Caregiver likes children & & & & & & - & & & - & & \\
\hline Caregiver is respectful to children & & & & & & - & घ & & & & \\
\hline Caregiver does not have a temper & & & & & & - & & & - & & \\
\hline Caregiver has a job & & a & & & & & - & - & - & & 曰 \\
\hline Caregiver's child rearing history & - & - & a & 口 & - & & - & 口 & & & \\
\hline $\begin{array}{l}\text { Caregiver's capacity to provide } \\
\text { stability and security }\end{array}$ & & & & & & - & & - & & & \\
\hline Child is allowed to bring possessions & & & & & & & & - & & & - \\
\hline $\begin{array}{l}\text { Caregiver's capacity to provide } \\
\text { structure and rules }\end{array}$ & & & & & - & & - & - & & & \\
\hline $\begin{array}{l}\text { Caregiver's capacity to provide } \\
\text { moral/spiritual guidance }\end{array}$ & & & & & & - & - & घ & - & & \\
\hline $\begin{array}{l}\text { Caregiver's capacity to provide the } \\
\text { child with direct supervision/day care }\end{array}$ & - & & & & & & - & & & & \\
\hline $\begin{array}{l}\text { Caregiver's willingness to follow agency } \\
\text { rules regarding discipline }\end{array}$ & - & & & - & & & & & & & \\
\hline Caregiver's capacity to provide adequate diet & - & & & & - & & - & & & & \\
\hline Caregiver's capacity to provide adequate housing & 口 & - & & & & & - & & & & \\
\hline Caregiver's neighborhood & & & & $\square$ & & & & & & - & 口 \\
\hline Caregiver's capacity to provide basic safety & & - & & - & & & & & & & \\
\hline Caregiver's access to transportation & - & & & & & & & & $\square$ & & \\
\hline Caregiver's financial capacity to care for the child & घ & 口 & & - & & - & & $\square$ & - & & \\
\hline Caregiver's general family relationships & - & - & & - & $\square$ & & & & - & & \\
\hline Fighting or domestic violence & - & & & & & - & & & & घ & \\
\hline Substance abuse & - & ! & & & $\square$ & $\square$ & - & - & & & \\
\hline $\begin{array}{l}\text { Availability of community and extended } \\
\text { family support }\end{array}$ & - & & a & घ & & & - & & & & \\
\hline
\end{tabular}

Note. The North Carolina counties are labeled A, B, C, D, and E. The Illinois site is labeled F. 
Table 4. Evaluation Criteria

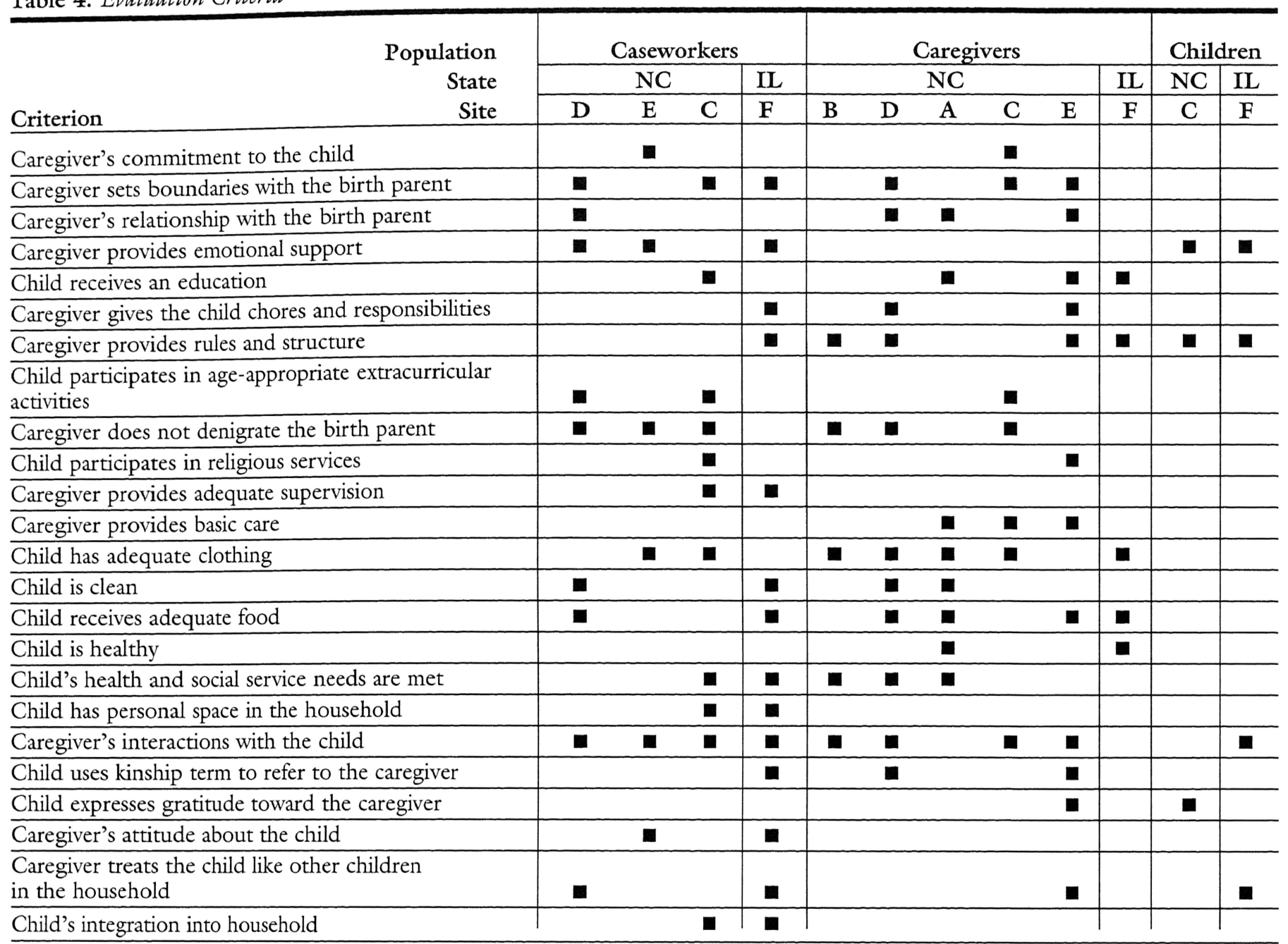

Note. The North Carolina counties are labeled A, B, C, D, and E. The Illinois site is labeled F.

tant that we make exceptions or waivers certainly. But at the same time, relatives need to be held up to a certain level of standards because too often kids are placed in bomes because they are relatives, and it doesn't mean the home is in their best interest or even appropriate. -Worker

Some workers felt that a prior felony conviction or substantiated maltreatment report should not automatically disqualify relatives from serving as caregivers; the agency should consider factors such as the severity of the incident, when the incident occurred, steps taken to change behavior, and behavior after the incident. One worker suggested that if the conditions in the household would not warrant removal of a child, then the home should be considered an acceptable placement for the child.

Protection of the Child From Continued Maltreatment. Due to the potential for increased contact between children and biological parents, some workers expressed difficulty in ensur- ing the child's protection in kinship settings. Caseworkers stressed the importance of exploring a caregiver's commitment and ability to comply with parental visitation rules outlined in case plans. Workers also felt that inappropriate contact between the parent and child is likely when the caregiver does not believe the allegations made against the parent. Some caregivers acknowledged the need to monitor and regulate parental visits and discussed setting rules and boundaries. These caregivers were most concerned with ensuring that parents did not visit when under the influence of drugs or alcohol.

In some cases, caregivers reported that their emotional attachment to the birth parent made it difficult to enforce rules. In other cases, workers and caregivers felt the natural parent's behavior was so extreme or volatile that the caregiver could not enforce the case plan or control visitation. In these cases, caregivers expressed their needs for the agency to assist them in managing these stressful and unpredictable situations.

In our case, we have the additional fear of the mother berself. It's not just the child's fear and insecurity, it's... 
I mean this girl, man, she can whip any of us. I mean she's just ... she's just a monster. - Caregiver

Discipline. Previous research has indicated that kinship caregivers are more likely than nonkinship foster caregivers to hold favorable views of physical punishment (Gebel, 1996). Caregivers in this study were therefore asked about their use of disciplinary techniques as an indicator of quality of care. The caregivers reported use of a wide range of strategies to encourage children to behave, such as "time out," positive reinforcement, loss of privileges and allowance, and object lessons. Participants expressed mixed views on the use of physical punishment to discipline children. Caseworkers and some caregivers indicated that spanking is not acceptable. Other caregivers, while aware of agency prohibitions against the use of physical punishment, admitted to spanking the children in their care as a last resort. These caregivers were careful in distinguishing between "spankings" and what they considered abuse.

Caregiver's Age and Health. Previous studies have found kinship caregivers to be older with more health problems when compared to nonkinship foster caregivers (Berrick et al., 1994; Gebel, 1996; LeProhn, 1994; Thornton, 1991). For this reason, participants were asked about the role age and health should play in selecting a relative to care for a child. Participants generally believed that while age should not play a role in selection, the caregiver's physical and mental health should allow him or her to provide care that meets the child's particular needs. Participants further stressed that care of the child should not pose a threat to the caregiver's health. Several groups discussed health factors that should potentially disqualify relatives from providing care: an HIV infection, a "nervous" personality, a mental condition, a chronic condition that would be worsened by child care, limited mobility, a contagious disease, a heart condition, or terminal illness. Caseworkers stressed that the impact of any health condition on a placing decision also depended on the child's capacity for self-care.

\section{Kinship Care Outcomes}

When asked about outcomes of importance in kinship care, caregivers tended to focus on the child's school performance, behavior, and general happiness (see Table 5).

Though few participants mentioned changes in kinship family dynamics as an outcome per se, many discussed the adverse effects of the placement on their relationships with spouses, children, grandchildren, and the child's other grandparents. For example, one participant cited an instance where the caregiver's children felt the relative's child received more attention.

Consistent with legal interpretations, social workers often described successful outcomes as the reunification of the child with the birth parent or adoption, with family reunification cited as the preferred outcome. From the perspective of many participants, a definition of permanency that limits acceptable permanency outcomes to reunification and adoption will "doom many kinship placements to failure." Several caregivers expressed an interest in adopting the child in their care, while others were openly hostile to the idea; they saw no need to "legally adopt a relative." For these caregivers and some caseworkers, permanency was not primarily a legal issue but an issue of the caregiver's long-term commitment to the child. Workers who embraced a broader definition of permanency and were more willing to accept other long-term kinship arrangements expressed frustration with constraining legal requirements for reunification or adoption. Others believed the transfer of legal custody to the relative caregiver indicated a successful kinship placement. Some caregivers expressed support for legal custody without agency involvement.

Perspectives on the impact of kinship care on the prospects for a child's reunification with the natural parents varied. Some participants believed that in the context of a positive parent-caregiver relationship, increased visitation and the caregiver's support could facilitate family reunification. Other caseworkers believed that kinship care made reunification with the child's natural parent more difficult due to the natural parent's psychological comfort in knowing that a relative is caring for their child. Workers felt that this comfort, combined with frequent contact between the child and parent, may undermine the parent's incentive to work toward reunification.

\section{Intervening Factors in the Quality of Care}

Agency activities can play a considerable role in determining the quality of care received by children in kinship care, especially for those caregivers requiring outside assistance. In general, many caregivers and caseworkers felt resentment and frustration concerning the treatment of kinship caregivers and the power imbalance between relative caregivers and the child welfare system as a whole, including the courts. One caregiver said, "You can not refuse [the agency] as I have ever heard of. Maybe you could, but most people probably aren't in that position." Both caregivers and caseworkers felt that agencies should correct power imbalances by involving caregivers more fully in the case planning process. Children also voiced their need for involvement in planning and placement decisions.

Comments about unfair treatment generally related to the licensing status of the caregiver. The Social Security Act defines the circumstances under which the federal government will reimburse states for Title IV-E foster care payments and provide Temporary Aid to Needy Families (TANF) benefits to dependent children. In Miller v. Youakim the U.S. Supreme Court held that the Social Security Act requires benefits to be paid to "any home that a state approves as meeting its licensing standards." When the lawsuit was filed in Illinois in 1973, only children in homes licensed by the state of Illinois were eligible to receive benefits. However, at that time, relative homes could not obtain a license under state law because Illinois 
Table 5. Outcome Measures and Intervening Factors

\begin{tabular}{|c|c|c|c|c|c|c|c|c|c|c|c|c|}
\hline \multirow[b]{3}{*}{ Criterion } & \multicolumn{4}{|c|}{ Caseworkers } & \multicolumn{6}{|c|}{ Caregivers } & \multicolumn{2}{|c|}{ Children } \\
\hline & \multicolumn{3}{|c|}{$\mathrm{NC}$} & \multirow{2}{*}{ IL } & \multicolumn{5}{|c|}{$\mathrm{NC}$} & \multirow{2}{*}{ IL } & \multirow{2}{*}{$\frac{\mathrm{NC}}{\mathrm{C}}$} & \multirow{2}{*}{\begin{tabular}{|c|}
$\mathrm{IL}$ \\
$\mathrm{F}$ \\
\end{tabular}} \\
\hline & $\mathrm{D}$ & $\mathrm{E}$ & $\mathrm{C}$ & & $\mathrm{B}$ & $\mathrm{D}$ & $\mathrm{A}$ & $\mathrm{C}$ & $\mathrm{E}$ & & & \\
\hline Child does well in school & & & & - & & 田 & & 四 & - & & & \\
\hline Child's behavior & & & & & - & & & 몸 & $\mathbf{a}$ & 嘈 & & \\
\hline Child is polite and respectful & & & & & & & 回 & & 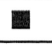 & & & \\
\hline Child is happy & & 囸 & & 四 & & & 畺 & & : & 国 & & 물 \\
\hline Child dresses appropriately & & & & & & & 畕 & & 䛛 & & & \\
\hline Child receives "permanency" & 国 & in & $=$ & - & & & & & & & & \\
\hline Child has contact with biological parents & & in & & & & & & & & & & - \\
\hline $\begin{array}{l}\text { Placement negatively impacts the caregiver's } \\
\text { family relationships }\end{array}$ & & & = & & - & 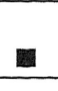 & & ㅁ. & . & 四 & & - \\
\hline \multirow[b]{3}{*}{ Criterion } & \multicolumn{4}{|c|}{ Caseworkers } & \multicolumn{6}{|c|}{ Caregivers } & \multicolumn{2}{|c|}{ Children } \\
\hline & \multicolumn{3}{|c|}{$\mathrm{NC}$} & IL & \multicolumn{5}{|c|}{ NC } & IL & $\mathrm{NC}$ & IL \\
\hline & $\mathrm{D}$ & $\mathrm{E}$ & C & $\mathrm{F}$ & B & $\mathrm{D}$ & A & $\mathrm{C}$ & $\mathbf{E}$ & $\mathrm{F}$ & $\mathrm{C}$ & $\mathbf{F}$ \\
\hline Level of financial assistance to caregivers & 囬 & 国 & 嘻 & & & & घ & 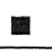 & 高 & & & \\
\hline Assistance with children's clothing & & - & 䛛 & & 몸 & & 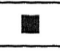 & & 四 & & & \\
\hline Assistance with medical care & & & & & - & 四 & 回 & & & & & \\
\hline Assistance with Christmas presents & & & - & & & $\mathbf{m}$ & & & & & & \\
\hline Timing of assistance & & & : & & - & & - & & 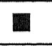 & & & : \\
\hline $\begin{array}{l}\text { Preplacement planning and preparation } \\
\text { of the kinship family }\end{array}$ & & & & - & 璂 & & & & & & & -1 \\
\hline Agency caseloads & & & 重 & & & & 田 & & & & & \\
\hline Supervision of kinship placements & - & 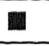 & - & & & & - & & & : & & \\
\hline Caregiver input in case planning and decision making & & & 㖥 & : & & & & - & & - & & \\
\hline Caseworker communication and support & & 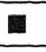 & & 国 & : & & 포 & $\mathbf{\square}$ & & $\mathbf{i n}$ & & 田 \\
\hline $\begin{array}{l}\text { Caseworker provision of information } \\
\text { re: services, policies, case status }\end{array}$ & & 모 & . & 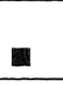 & & & 물 & & - & & & 모 \\
\hline Training for caregivers & & - & 四 & & & & & & - & & & \\
\hline Provision of day care & - & & 鿷 & & & & - & & 高 & & & \\
\hline Provision of counseling for children in care & & & & & 몰 & & & & - & & & \\
\hline Provision of support groups for caregivers & & 口 & 㗂 & & & & & & $\mathbf{n}$ & & & \\
\hline
\end{tabular}

Note. The North Carolina counties are labeled A, B, C, D, and E. The Illinois site is labeled F.

defined a "foster family home" to include only those facilities providing family care to children unrelated to them. The Supreme Court found it inconsistent with federal law for Illinois to approve related homes as meeting its licensing standards but then to deny benefits to those same homes on the ground that they were not actually licensed (see Miller, 440 U.S. at 135; Youakim, 562 F.2d at 487). In the context of this 1976 ruling, wide variation in the licensing, approval, and support to relative homes developed within and between states (Berrick, et al. 1994; Chipman, et al. 2000). At the time the focus groups were conducted, North Carolina's kinship licensing policies and practices varied by county. North Carolina caseworkers had mixed opinions about the desirability of licensing relatives, with the debate typically focused on the difference in funds available to licensed and nonlicensed homes. Some caseworkers believed that kinship caregivers should not received additional funds because "families are obligated to take care of their own." One worker said, "My thought was, how money hungry are they if they can't take care of their own grandkids?"

Generally, caseworkers felt that families needed and should be entitled to the assistance provided to nonkinship foster families, though others expressed reservations for other reasons. In one county, caseworkers worried that licensing kinship homes would strain agency resources while other caseworkers believed licensing would negatively impact the agency's capacity to relinquish custody of children to the caregiver.

As an agency we try not to [license relatives] very much because we continue to have custody of those children until they turn 18. They belong to a foster care case and plan. We try to focus on giving relatives custody of children for 1 year if parents do not get their act together so that we're out of it. -Worker 
Not surprisingly, many caregivers in North Carolina did not know that they could become licensed, suggesting that local agencies do not regularly inform kinship caregivers of this option.

Illinois has promulgated statewide policies intended to facilitate the licensing of relatives through its Home of Relative Reform (Testa, 1993). Though Illinois caseworkers stated that they provide the same level of service to relatives regardless of licensure, resentment concerning financial issues was also a principal topic of Illinois caregiver discussions. Some caregivers expressed resentment about licensing requirements though most recognized that licensing served to protect children. Many caregivers reported difficulties in obtaining licenses, especially due to criminal histories. They also reported that private agencies would advocate for caregivers and help them obtain a license while IDCFS would not.

Overall, participants felt that financial assistance and services should be provided or arranged for by the placing agency (see Table 5). Many North Carolina participants indicated that kinship caregivers without insurance need help paying for the child's medical expenses. African American caregivers often discussed the need for funds for clothing. Other common service needs included day care, support groups for caregivers, tutoring services, counseling for caregivers, counseling for children, and training for caregivers. Children reported needs for support groups for themselves and shared concerns about their caregivers receiving assistance in a timely manner. Illinois caregivers had few complaints about the services provided but believed that the level of services provided depended upon the child welfare agency serving the placement.

\section{My granddaughter that was with me, she was pregnant when they brought her back. I had a bideaway bed for her to sleep on. I asked [Agency A] if they could get her a bed by the time she had her baby. They said, "No, we think we give you enough money to buy that." When [Agency B] came about a week later and took over their case, the caseworker said, "What do you need?" I said, "Well I asked for another hideaway bed, but they told me they wouldn't get me one." She said, "Just tell me what you need." - Caregiver}

Participants indicated that even when services and resources were available to kin, caregivers were not always aware of their existence. In one group, many caregivers lacked basic knowledge about the services available, how to access the services, and the status of the child's case. Others indicated long delays in receiving information about funds and services available to them. Some caregivers were afraid to request services because they feared the children in their care would be removed from their homes.

Caregivers also discussed the need for caseworker support in dealing with generational differences and the special needs of the children in their care. In some cases, requests were made for common courtesy.

\begin{abstract}
I think that the placement person, that they need to be more supportive.... Like when I call with a question ... it's like the answer that I get is kind of negative. I mean, it's not negative, but it's like in a burry so they can just get you off the phone. It's like, we really don't bave time to listen to your problem. - Caregiver
\end{abstract}

\section{Discussion}

Participants' perspectives reflect some areas of agreement with existing standards for assessing and evaluating the quality of kinship homes, such as the importance of the relationship between the child and relative, and the caregiver's ability to meet the child's developmental needs. The findings also stress constructs that build upon and add depth to the current standards.

In keeping with the overarching goals of child welfare intervention, caseworkers tend to focus on child safety and permanency issues in placement decisions. Caregivers, however, focus on the ability to provide children with love and moral and spiritual guidance. Along these lines, caregivers viewed school performance, appropriate behavior, and happiness as important outcomes of kinship care while the main outcome of consideration for caseworkers was the child's permanency status. These differences in perspective are important reminders of the responsibilities that families see for themselves, even when workers may not focus on accountability in these areas. Current assessment standards can be enhanced by including the caregiver's expectations for the placement, thereby enhancing the caseworker's ability to assist the family in meeting the caregiver's goals as well as the goals of the case plan.

The caregiver's ability to meet the child's needs certainly relates to the caregiver's age and health status, considerations present in existing standards for kinship foster family assessment. Participants in this study generally agreed that age should not be a factor in caregiver selection, but that the caregiver's physical and mental health should be considered relative to the child's needs and capacity for self-care. Participants went on to outline an array of conditions that should disqualify relatives from providing care. In relation to the caregiver's ability to provide physical care, some participants, including children, also expressed preferences for employed and financially stable caregivers. Though not explicit in existing standards, the caregiver's financial ability to meet the child's needs, and whether that ability could be enhanced through available funding, should be made part of any assessment prior to placement.

Participant perspectives also reflect consensus on the need for caregivers to be able to protect the child from the parent and from negative dynamics in and around the family home such as criminal activity, child maltreatment, domestic violence, and substance abuse. Existing standards address the 
presence of substance abuse but appear to limit the assessment to the kinship home. Though the issue of substance abuse has not been well-developed in the foster care evaluation literature, in this study, caseworker concerns extended beyond substance abuse in the immediate home to the caregiver's ability to handle the substance abusing biological parent. Will the caregiver be able to set boundaries? Can the caregiver provide adequate protection when the parent is using substances? Caseworkers and caregivers also expressed concern about the caregivers' representation of the biological parent to the child. Does the caregiver have the skills to preserve a relationship between a substance abusing parent and child? If not, how can the caregiver be assisted?

Another dimension of the caregiver's ability to protect the child involves the safety of the caregiver's neighborhood. Children in kinship care in the Fox and others (2000) study were more frequently exposed to violence in their neighborhoods when compared to children in nonkinship care. In this study, both of the children's groups identified the caregiver's neighborhood as an important selection criterion. Several caseworkers believed that kinship homes should protect children from hazards in the physical environment in and around the home. This construct is absent from current standards and should be given consideration in the context of other criteria.

Another safety concern relates to the caregiver's approach to discipline. Previous research has suggested that kin caregivers are more likely to hold favorable views of physical punishment (Gebel, 1996). Careful to distinguish between what they considered spanking and abuse, some caregivers in this study also admitted spanking the children in their care as a last resort. Assessment of the caregiver's attitudes toward physical discipline and knowledge of alternative techniques can indicate early on whether the caregiver will need assistance in employing appropriate discipline before problems surface that may require the child's removal from the home. Interpretations of abusive and nonabusive behaviors may further relate to the caregiver's beliefs about the validity of allegations made against the child's parent and/or the caregiver's beliefs about the child's exposure to danger prior to placement (Berrick et al., 1994). An existing standard related to this construct concerns the possibility that family members will pressure a child to recant allegations of abuse. This construct may be supported by the caregiver's beliefs about abusive behaviors and/or the allegations made, though other factors, such as threats or pressure from other family members, may also play a role.

\section{Recommendations for Policy, Practice, and Future Research}

Over the course of discussions held with caregivers, caseworkers, and children in kinship placements, several policy and practice issues emerged concerning the factors that mediate the process and outcome of kinship care. Some of the practices described, such as emergency placements followed by assessments, uneven provision of benefits, and unequal treatment of caregivers, have likely resulted from insufficient resources and inconsistent policies concerning kinship care. Only recently has consistency in the licensing standards that states apply to kinship and nonkinship foster caregivers been required for federal foster care reimbursement (U.S. Department of Health and Human Services, 2000). As responses from caseworkers and caregivers suggest, consistency simultaneously creates benefits and new burdens for states, such as ineligibility or disinterest in licensing. Clearly, for some kinship caregivers, receiving a license to care for a niece or a nephew seems ludicrous. For the same reasons, these foster caregivers would likely see no reason to "legally adopt a relative" but would accept an alternative permanency option such as guardianship. In the past, states have resolved these issues through the provision of welfare benefits, no benefits, or through fully state-funded placements; a costly proposition. Greater latitude in the use of federal funds is needed to provide families with a range of permanency options and to support state innovations. Along these lines, substantial modification will need to be made to the current Title IV-E waiver process to allow for more flexibility and encourage state participation in demonstrations.

In the meantime, changes in practice can go a long way in ameliorating some of the problems that broader policy issues have produced. Unplanned placements raise obvious child safety issues and create problems for members of the caregiver's household, which in turn affect the well-being, and in some cases, the safety of the child placed. For example, some workers reported that placements would have been avoided if more complete information had been available at the time of placement. As child welfare continues to increasingly place the burden of child protection onto kinship caregivers, stakeholders must be included in the case planning process to gain consensus on the goals of placement and achieve the outcomes envisioned within required time frames. 
Wherever possible, agencies should prepare families by involving children, kinship families, and biological parents in case planning to discuss the child's needs and each party's expectations of the placement. This practice is in line with the recent movement toward family conferencing, which has been implemented in many agencies. As an assessment tool, the model provides the opportunity for comprehensive case planning and information sharing with multiple parties at once. As a decision making approach, families are included as an integral part of the process and empowered to make appropriate choices to ensure child safety (American Humane Association, 2000; Pennell \& Burford, 2000).

A related practice issue and an area for future research concerns the uneven provision of resources and support to foster caregivers. These findings are again, we believe, the product of insufficient resources and inconsistent policies. On the one hand, agencies need the flexibility to make determinations of how the needs of the kinship placement can best be met while controlling costs. On the other hand, any space left for subjective decision making opens the door for inconsistencies. Nonetheless, findings from the research literature suggest that kinship caregivers-who are more often older, African American, single, and female head of households with lower income, less education, and more health problems-need more support rather than less to care for younger children who suffer from more emotional and mental health problems than children in the general population. Overall, a lack of information and insufficient financial assistance and services was cited by caregivers as the major difference between kinship care and regular foster care. Caregivers reported needing more support from their caseworkers than was available.

Many caseworkers and caregivers also believed that kinship cases received less monitoring than other placements. One worker acknowledged that the low level of agency monitoring in kinship cases may have implications for child safety. As one caregiver said, "Ain't nobody called me. [The agency] don't know that mine is living or dead. They don't know."

The role that the nature and degree of agency support and communication with kinship caregivers play in the quality and outcome of care represents an important area for future study. Future research should also examine caregiver cooperation and contact with the placing agency and an examination of the personal and legal factors that may mediate the quality and outcome of placement.

Another practice concern and issue for future study relates to contact between children and biological parents in kinship foster care settings. In this study, caseworkers questioned some caregivers' ability to comply with the parental visitation rules outlined in case plans. Likewise, caregivers reported that their emotional attachment to the birth parent made it difficult to enforce rules. As a general rule, kinship placements or visitation may not be appropriate when a potentially violent parent directs anger toward the caregiver or is generally out of control, especially if the agency is unable to assist the caregiver in carrying out this component of the case plan. To ensure child safety, caregivers must develop a plan for protecting the child during visitation and determine with the caseworker whether their efforts are likely to be successful. The issue of the child's protection from abusive biological parents, and the possible benefits to the child of ongoing parental contact and increased contact with siblings, are areas of evaluation specific to kinship care which are considerably underdeveloped in the research literature. Child welfare experts have suggested that the evaluation of the kinship family's relationship with the child and the child's biological family is particularly relevant for kinship care (Dubowitz, 1994). While the conceptual work is clear on this subject, empirical investigation in this area is also needed.

\section{References}

American Bar Association. (1999, February). Policy resolution on kinship care of abused, neglected, and abandoned children. Chicago, IL: Author.

American Humane Association. (2000). 1999 national roundtable on family group decision making: Summary of proceedings. Inglewood, CO: Author.

Barth, R. P., Courtney, M., Berrick, J. D., \& Albert, V. (1994). From child abuse to permanency planning: Child welfare services, pathways and placements. Hawthorne, NY: Aldine de Gruyter.

Benedict, M., \& White, R. (1991). Factors associated with foster care length of stay. Child Welfare, 70, 45-58.

Benedict, M., Zuravin, S., \& Stallings, R. (1996). Adult functioning of children who lived in kin versus nonrelative family foster homes. Child Welfare, $75,529-549$.

Berrick, J. D. (1996). Assessing quality of care in kinship and foster family care. Berkeley, CA: University of California at Berkeley, School of Social Welfare.

Berrick, J. D., Barth, R. P., \& Needell, B. (1994). A comparison of kinship foster homes and foster family homes: Implications for kinship foster care as family preservation. Children and Youth Services Review, 16, 33-63.

Child Welfare League of America. (1994). Kinship care: A natural bridge. Washington, DC: Author.

Chipman, R., Shepherd, K., \& Wells, S. J. (2000). Kinship care: The state of the states. Urbana, IL: University of Illinois, School of Social Work.

Courtney, M. (1994). Factors associated with the reunification of foster children with their families. Social Service Review, 68, 81-108.

Dubowitz, H. (1994). Kinship care: Suggestions for future research. Child Welfare, 73, 553-564.

Dubowitz, H., Feigelman, S., Harrington, D., Starr, R, Zuravin, S., \& Sawyer, R. (1994). Children in kinship care: How do they fare? Children and Youth Services Review, 16, 85-106.

Dubowitz, H., Feigelman, S., \& Zuravin, S. (1993). A profile of kinship care. Child Welfare, 72, 153-169.

Dubowitz, H., Feigelman, S., Zuravin, S., Tepper, V., Davidson, N., \& Lichenstein, R. (1992). The physical health of children in kinship care. American Journal of Diseases of Children, 146, 603-614.

Dubowitz, H., \& Sawyer, R. (1994). School behavior of children in kinship care. Child Abuse and Neglect, 18, 899-911.

Everett, J. E. (1995). Relative foster care: An emerging trend in foster care placement policy and practice. Smith School of Social Work, 65(3), 239-254.

Fontana, A., \& Frey, J. H. (1994). Interviewing: The art of science. In N. K. Denzin \& Y. S. Lincoln (Eds.), Handbook of qualitative research (pp. 361-376). London, UK: Sage.

Fox, A., Frasch, K., \& Berrick, J. D. (2000). Listening to children in foster care: An empirically based curriculum. Berkeley, CA: Child Welfare Research Center. 
Gebel, T. (1996). Kinship care and non-relative family foster care: A comparison of caregiver attributes and attitudes. Child Welfare, 75, 5-18.

Gleeson, J. (1996). Kinship care as a child welfare service: The policy debate in an era of welfare reform. Child Welfare, 75, 419-449.

Gleeson, J., \& Craig, L. (1994). Kinship care in child welfare: Analysis of states' policies. Children and Youth Services Review, 16, 7-31.

Goerge, R. (1990). The reunification process in substitute care. Social Service Review, 64, 422-457.

Gray, S., \& Nybell, L. (1990). Issues in African-American family preservation. Child Welfare, 69, 513-523.

Iglehart, A. (1994). Kinship foster care: Placement, services, and outcome issues. Children and Youth Services Review, 16, 107-122.

Jarrett, R. L. (1993). Interviewing with low-income minority populations. In D. L. Morgan (Ed.), Successful focus groups: Advancing the state of the art (pp. 184-201). London, UK: Sage.

Laird, J. (1979). An ecological approach to child welfare: Issues of family identity and continuity. In C. B. Germain (Ed.), Social work practice: People and environments (pp. 174-209). New York: Columbia University Press.

LeProhn, N. (1994). The role of the kinship foster parent: A comparison of the role conceptions of relative and non-relative foster parents. Children and Youth Services Review, 16, 65-84.

Lewis, R, \& Fraser, M. (1987). Blending informal and formal helping networks in foster care. Children and Youth Services Review, 9, $153-169$.

Morgan, D. L., \& Krueger, R A. (1993). When to use focus groups and why. In D. L. Morgan (Ed.), Successful focus groups: Advancing the state of the art (pp. 3-19). London, UK: Sage.

Padgett, D. K. (1998). Data collection. In D. K. Padgett (Ed.), Qualitative methods in social work research: Challenges and rewards (pp. 55-71). London, UK: Sage.

Pennell, J, \& Burford, G. (2000). Family group decision making: Protecting children and women. Child Welfare, 79(2), 131-158.

Takas, M. (1992). Kinship care: Developing a safe and effective framework for protective placement of children with relatives. Children's Legal Rights Journal, 13(2), 12-19.

Takas, M. (1994). Kinship care and family preservation: Options for states in legal and policy development. Washington, DC: American Bar Association.
Testa, M. (1992). Conditions of risk for substitute care. Children and Youth Services Review, 14(1), 27-36.

Testa, M. (1993). Home of relative (HMR) program in Illinois: Interim report. Chicago, IL: University of Chicago, School of Social Service Administration.

Testa, M., Shook, K., \& Cohen, L. (1996). Permanency planning options for children in formal kinship care. Child Welfare, 75, 451-470.

Thornton, J. (1991). Permanency planning for children in kinship foster care. Child Welfare, 70, 593-601.

U.S. Department of Health and Human Services. (2000, January 25). Title IVE foster care eligibility reviews and child and family services state plan reviews: Final rule. Federal Register, 65(16). Washington, DC: Government Printing Office.

Whittaker, J. (1986). Formal and informal helping in child welfare service: Implications for management and practice. Child Welfare, 45, 17-25.

Whittaker, J., \& Garbarino, J. (1983). Social support networks: Informal belping in the human services. New York: Aldine de Gruyter.

Wulczyn, F., \& Goerge, R. (1992). Foster care in New York and Illinois: The challenge of rapid change. Social Service Review, 66, 278-294.

Robert Chipman is analytic consultant, Chambers Associates, Washington, DC. Susan J. Wells is Gamble-Skogmo Professor in Child Welfare and Youth Policy, School of Social Work, Peters Hall, Room 105, 1404 Gortner Avenue, University of Minnesota, St.Paul, MN 55108; e-mail: sjwells@umn.edu. Michelle A. Johnson is a doctoral student in Social Welfare at the University of California, Berkeley.

Authors' note: This study was funded under USDHHS Contract \# 90CW1091 by the Children's Bureau, Administration for Children Youth and Families, U.S. Department of Health and Human Services, Susan J. Wells, Principal Investigator. This article was completed with additional support from the University of Illinois School of Social Work, UrbanaChampaign, IL.

Manuscript received: September 18, 2000

Revised: December 13, 2001

Accepted: January 24, 2002 